\title{
Hubungan antara Penagihan Dadah dengan Keganasan Rumah Tangga
}

\author{
(The Relationship between Drug Addiction and Domestic Violence)
}

\author{
VICTOR ISAACS \\ NASIR MOHAMAD \\ LIYANA HAZWANI MOHD ADNAN \\ WAN HANIS AISYAH WAN ROSDI \\ NOR SULIANA MUSTAFA \\ NURUL FARAH AINA MD FAUZI \\ NUR HUSNA ZAKARIA
}

\begin{abstract}
ABSTRAK
Pertubuhan Kesihatan Sedunia (WHO) dan negara-negara anggotanya melalui Resolusi Perhimpunan Kesihatan Sedunia 49.25 telah mengakui bahawa keganasan adalah masalah awam yang serius dan juga merupakan suatu pencabulan hak asasi manusia. Di Malaysia, istilah "keganasan rumah tangga” merujuk kepada keganasan yang dilakukan oleh pasangan terhadap isteri atau orang yang disayangi. Statistik menunjukkan bahawa kes penagihan dadah meningkat seiring dengan peningkatan jumlah kes keganasan rumah tangga. Objektif kajian ini ialah untuk mengkaji perspektif responden berkenaan keganasan rumah tangga terutamanya dalam kalangan pengguna-pengguna opiat di Malaysia khususnya di Terengganu seterusnya kesan penagihan dadah terhadap keharmonian rumah tangga. Kaedah pengajian prospektif telah dijalankan dalam tempoh enam bulan ke atas 30 orang penagih opiat yang sedang menerima rawatan Terapi Gantian Metadon (TGM) di sekitar Kuala Terengganu dengan menggunakan borang kaji selidik. Analisis deskriptif digunakan untuk menganalisis data dalam kajian kuantitatif. Kajian ini menggunakan perisian SPSS versi 22.0\%.Hasil kajian memfokuskan hubungan kekeluargaan, perlakuan, tingkah laku serta emosi di antara respondan dan pasangan. Keputusan menunjukkan bahawa hampir 80.0\% responden tidak mempunyai sejarah penderaan sebelum ini dan tidak melakukan keganasan rumah tangga terhadap pasangan mereka. Sebanyak 39.4\% responden sangat bersetuju bahawa keganasan rumah tangga adalah jenayah, berbanding 7.1\% responden yang tidak bersetuju. Seterusnya, data menunjukkan bahawa 36.0\% responden bersetuju bahawa layanan mereka terhadap pasangan berubah setelah mengambil dadah. Data juga membuktikan bahawa sebanyak $22.0 \%$ responden merasakan pasangan mereka berasa risau dan takut apabila bersama mereka. Hasil daripada analisis data menunjukkan bahawa kebanyakan responden merupakan individu yang mampu menjalani kehidupan normal sebelum pengambilan dadah. Walau bagaimanapun, setelah pengambilan dadah, perubahan pada tingkah laku dan emosi responden menyebabkan berlakunya keganasan dalam rumah tangga dan terhadap keluarga. Hal ini seterusnya menyebabkan pasangan berasa tidak selamat apabila bersama responden.
\end{abstract}

Kata kunci: Keganasan rumah tangga; pengguna opiat

\section{ABSTRACT}

The World Health Organization (WHO) and its member states through the World Health Organization Resolution 49.25 have recognized that violence is a serious public problem and also a violation of human rights. In Malaysia, the term "domestic violence" refers to the violence perpetrated by a spouse against another spouse or loved one. To address cases of abuse of women, statistics show that drug addiction cases increase with the increasing number of domestic violence cases. The objective of this study was to study the respondents 'perspectives on domestic violence especially among opiate consumers in Malaysia especially in Terengganu and the effect of drug addiction on household harmony. The prospective study was conducted over a period of six months with 30 ophthalmologists receiving Metadon Replacement Therapy (TGM) treatment in Kuala Terengganu using a survey form. Descriptive analysis is used to analyze data in quantitative studies. This study used SPSS software version 22.0. The results of this study focused on the family, behavior, character and emotional relationships between the respondents and their spouses. The results showed that almost $80 \%$ of respondents had no previous history of abuse and did not commit domestic violence against their spouses. A total of $39.4 \%$ of respondents strongly agreed that domestic violence is a crime, compared with $7.1 \%$ of respondents who disagree. Further, the data shows that $36 \%$ of respondents agreed that their treatment of their spouses changed after taking drugs. Data also shows that $22 \%$ of respondents feel that their spouses anxious and scared when they 
are with them. Results from the data analysis show that most respondents are individuals who can lead a normal life before taking drugs. However, after taking drugs, changes in respondents' behavior and emotions led to domestic and family violence. This in turn causes the spouses to feel insecure when with the respondents.

Keywords: Domestic violence; opiate consumers

\section{PENDAHULUAN}

Keganasan rumah tangga boleh dibahagikan kepada lima kategori iaitu; fizikal, seksual, psikologi, ekonomi serta kekerasan terhadap emosi dan identiti. Keganasan fizikal melibatkan percubaan untuk melakukan kekerasan sehingga menyebabkan berlakunya kecederaan fizikal. Selain itu, menghalang dan mengabaikan keperluan mangsa untuk mendapatkan rawatan kesihatan juga boleh dikategorikan sebagai keganasan fizikal. Keganasan seksual pula melibatkan paksaan dan cubaan untuk melakukan hubungan seks terhadap mangsa serta menghina seksualiti mangsa. Keganasan emosi pula melibatkan penghinaan terhadap harga diri mangsa serta melakukan perbuatan yang melibatkan kekerasan terhadap identiti mangsa seperti menganiaya emosi dan psikologi mangsa. Manakala, keganasan psikologi pula melibatkan pelaku membuatkan mangsa berasa takut dengan cara ugutan atau paksaan. Selain itu, keganasan psikologi juga boleh dilakukan dengan mengasingkan atau menjauhkan mangsa daripada keluarga terdekat dan orang-orang yang mereka sayangi. Akhir sekali, kekerasan ekonomi melibatkan pelaku menyekat kewangan ekonomi dan membuat mangsa bergantung kewangan kepada mereka ${ }^{1}$ (Hanafi \& Rohani 2015).

Pada tahun 1994, Akta Keganasan Rumah Tangga telah ditubuhkan di dalam perundangan negara. Hal ini menunjukkan kes keganasan rumah tangga tidak lagi dipandang remeh dan dianggap sebagai perkara sulit kerana ia berbentuk peribadi kepada mangsa. Ia diklasifikasikan sebagai satu masalah sosial di dalam masyarakat. Keganasan rumah tangga telah diiktiraf oleh negara Malaysia sebagai satu jenayah besar di bawah kanun keseksaan dan boleh disabitkan kesalahan kepada si pelaku. Sebelum wujudnya akta ini, persatuan dan pertubuhan wanita telah berusaha keras selama 10 tahun dengan memujuk kerajaan agar perkara ini dipandang serius dan dijadikan perkara yang boleh disepakati oleh masyarakat dan kerajaan. Hasil usaha mereka tidak siasia dan membuahkan hasil kerana kini wanita-wanita di Malaysia boleh mendapatkan bantuan daripada pelbagai pihak seperti agensi-agensi kerajaan (Contoh: polis, Jabatan Kebajikan Masyarakat, hospital, dan klinik kesihatan) serta agensi-agensi bukan kerajaan atau lebih dikenali sebagai "Non-Governmental Organisations (NGO)" yang boleh membantu wanita-wanita yang dianiaya dengan mengambil tindakan terhadap mereka yang melakukan keganasan.

Walaupun begitu, Malaysia masih lagi mengalami masalah peningkatan kadar keganasan rumah tangga yang tinggi terutamanya dalam kalangan penagih sejak tahun 2010. Mantan Menteri Pembangunan Wanita, Keluarga dan Masyarakat, Datuk Rohani Abdul Karim telah mendedahkan bahawa sebanyak 3173 kes keganasan rumah tangga telah berlaku, melibatkan 2522 wanita dan 650 lelaki. Secara keseluruhannya, terdapat 2329 penagih dadah lelaki dan 63 penagih dadah perempuan di Negeri Terengganu dari tahun 20132016 (AADK 2016). Jumlah penagih dadah yang terlibat dengan keganasan rumah tangga semakin meningkat setiap tahun dan data menunjukkan bahawa peningkatan jumlah penagih dadah adalah sama atau sekata dengan peningkatan kes keganasan rumah tangga ${ }^{3}$ (AADK 2016). Hal ini menunjukkan bahawa ketagihan merupakan salah satu faktor yang menyebabkan berlakunya kes keganasan rumah tangga.

Selain itu, pusat pemulihan dadah di Amerika yang dikenali sebagai The Recovery Village, Florida berpendapat bahawa keganasan rumah tangga dan penggunaan dadah berkait rapat di antara satu sama lain serta lebih cenderung untuk berlaku pada waktu yang sama. Hubung kait yang sama juga didapati dengan pertambahan penggunaan dadah dan masalah mental seperti kebimbangan dan kemurungan. Simptomsimptom ini berkait rapat di antara satu sama lain tetapi tidak semestinya salah satu akan mendahului yang lain. ${ }^{4}$ Penggunaan dadah tidak semestinya menyebabkan si pelaku melakukan keganasan fizikal dan emosi. Kita juga tidak boleh merumuskan bahawa mangsa penderaan akan terjebak dengan dadah atau bahan-bahan yang terlarang. Namun begitu, terdapat bukti yang menunjukkan si pelaku yang terbabit dengan penggunaan dadah lebih berkemungkinan untuk melakukan keganasan rumah tangga. Kombinasi karakter ini tanpa ragu-ragu akan memberi kesan yang negatif kepada ramai orang. ${ }^{5}$ Pelbagai agensi kerajaan dan organisasi telah membuktikan bahawa dadah dan keganasan mempunyai hubung kait antara satu sama lain. Tanpa mengira karakter mana dahulu yang terdapat dalam diri si pelaku (sama ada si pelaku seorang penagih dadah dan kemudian melakukan keganasan rumah tangga atau si pelaku melakukan keganasan rumah tangga terlebih dahulu kemudian baru terjebak dengan dadah), apa yang pasti mempunyai kedua-dua elemen ini di dalam seorang individu boleh menambahkan dan meningkatkan kesan yang berlaku. Corak yang jelas dapat dilihat berkaitan dengan kesalahan yang dilakukan akibat kesan dari penyalahgunaan dadah dari segi tingkah laku mereka serta menyebabkan tercetusnya keganasan. ${ }^{6}$ 
Kes keganasan rumah tangga juga kebiasaannya berlaku dalam keluarga yang bermasalah dan tidak harmoni. Keluarga bermasalah ialah keluarga yang mempunyai masalah dalam pelbagai bentuk seperti masalah ekonomi atau kewangan, salah faham antara pasangan suami isteri, anak-anak yang bermasalah, campur-tangan orang luar, masalah kesihatan pasangan dan sebagainya. Kecelaruan di dalam hubungan kekeluargaan akan menyebabkan timbulnya perasaan marah, tidak berpuas hati, dendam dan kecelaruan emosi hingga menyebabkan seseorang itu ingin mengugut, mencederakan fizikal, menghina dan mengeluarkan kata-kata yang kesat dan akhir sekali timbulnya perasaan ingin membunuh pasangan atau ahli keluarga yang lain. Apabila perasaan itu timbul, maka seseorang itu akan berniat untuk menzahirkan perasaan tersebut dalam bentuk tingkah laku bagi memuaskan hati dan jiwa mereka. Oleh itu, keganasan rumah tangga dan penganiayaan kepada pasangan akan berlaku apabila masalah rumah tangga tidak dapat diselesaikan secara aman dan baik. ${ }^{7}$ Salah satu jalan penyelesaian kepada masalah ini ialah melalui penguatkuasaan golongan dan peranan komuniti setempat.

\section{PERANAN KOMUNITI DALAM MENANGANI KEGANASAN RUMAH TANGGA}

Adalah penting untuk menanam semangat kemasyarakatan dalam sesebuah komuniti. Ia adalah salah satu cara yang boleh digunakan bagi mengatasi dan mengurangkan kes keganasan rumah tangga. Cara ini bukanlah disarankan bertujuan untuk menanam sikap penyibuk dalam kalangan komuniti dan jiran tetangga tetapi untuk menanam elemen boleh mempercayai di antara satu sama lain. Hal ini adalah penting untuk mengingatkan kepada setiap orang terutamanya mangsa bahawa terdapat jiran-jiran yang prihatin, yang sentiasa akan memerhati dan menjaganya demi kepentingan mangsa itu sendiri. Oleh itu, kejadian-kejadian yang tidak diingini dalam keganasan rumah tangga seperti mencederakan atau memukul mangsa akan dapat dielakkan kerana ia diketahui dan dipantau oleh jiranjiran mereka. ${ }^{8}$

Semangat kemasyarakatan perlu diperkuatkan dan ditanam semula dalam hati dan minda masyarakat masa kini bagi memperkuatkan keharmonian dan kedamaian negara kita. Semangat yang dibina hendaklah berdasarkan prinsip Rukun Negara yang telah digubal pada 31 Ogos 1970 seperti: ${ }^{9}$

1. Kepercayaan kepada Tuhan;

2. Kesetiaan kepada Raja dan Negara;

3. Keluhuran Perlembagaan;

4. Kedaulatan Undang-Undang; dan

5. Kesopanan dan Kesusilaan.

"The Golden Rule" yang diamalkan oleh semua agama dan diterima oleh orang ramai telah menyatakan bahawa "layanlah orang lain sepertimana kamu mahu dilayan." Kata-kata inilah menyemat semangat kejiranan dan persepaduan dalam kalangan rakyat. Penderaan dan keganasan akan terus berlaku jika orang ramai tidak mahu masuk-campur dan berbuat sesuatu untuk menghentikannya. ${ }^{10}$

Keganasan rumah tangga bukan lagi masalah peribadi seseorang. Jika kita tidak menghentikannya sekarang, jumlah keganasan rumah tangga akan semakin meningkat. Adalah penting bagi pihak-pihak yang terbabit untuk menyediakan sokongan terhadap mangsa dan juga si pelaku seperti kaunseling untuk trauma. Mangsa penderaan yang tidak mendapat sokongan yang secukupnya akan lebih cenderung untuk menjadi pendera pada masa akan datang.

\section{OBJEKTIF DAN SKOP KAJIAN}

Oleh itu, objektif kajian ini ialah untuk memahami dengan lebih mendalam mengenai keganasan rumah tangga serta untuk mengkaji faktor-faktor yang menyebabkan berlakunya keganasan tersebut dalam kalangan pengguna opiat di Terengganu.

Kajian ini melibatkan penagih dadah opiat yang sedang menjalani Terapi Gantian Metadon dan telah berkeluarga di Negeri Terengganu. Hal ini adalah bertujuan untuk mendapatkan maklumat mengenai penagih dadah di Terengganu serta menyiasat faktorfaktor yang menyebabkan berlakunya keganasan rumah tangga.

\section{METODOLOGI KAJIAN}

Kajian ini berbentuk kajian keratan rentas. Keratan rentas ialah satu kajian yang merupakan kajian pemerhatian dengan mengukur pembolehubah secara individu, mengukur hasil dan mengumpul maklumat yang diperlukan dalam satu jangka masa yang telah ditetapkan. Kajian keratan rentas merupakan satu kajian yang mana hanya satu kumpulan diperlukan untuk mengumpul data, dan pelbagai hasil kajian dapat diperolehi ${ }^{11}$ (Mann 2003). Kajian ini biasanya dilakukan dengan menggunakan borang soal selidik. Oleh itu, kajian yang menggunakan kaedah keratan rentas memerlukan kos yang rendah. Pemilihan penggunaan reka bentuk keratan rentas dalam kajian ini di perkukuhkan lagi yang mana menerusi kajian keratan rentas, sesebuah kajian dapat dilakukan dalam tempoh yang singkat dengan kos yang murah ${ }^{12}$ (Sedgwick 2014). Selain itu juga, kajian ini juga dikenali sebagai kajian prevelen yang memberikan pendedahan penuh terhadap sesebuah populasi serta penerangan tentang diagnosis sesuatu penyakit. 


\section{ETIKA PENYELIDIKAN}

Pengkaji membuat permohonan etika untuk melakukan penyelidikan daripada pihak Universiti Sultan Zainal Abidin. Pengkaji juga bertanggungjawab untuk menjaga kerahsiaan responden semasa kajian dilakukan untuk menjaga sensitiviti responden. Di samping itu, pengkaji juga memilih responden yang sukarela dan bersetuju untuk menjawab borang soal selidik.

\section{POPULASI KAJIAN}

Populasi sasaran kajian ialah penagih dadah yang mengambil opiat (metadon) yang sedang menjalani Terapi Gantian Metadon (TGM) di Klinik Kesihatan Bukit Tunggal, Kuala Terengganu.

\section{KRITERIA PEMILIHAN RESPONDEN}

Terdapat beberapa kriteria penerimaan dan penolakan subjek yang perlu dipatuhi di dalam kajian ini. Hal ini bertujuan untuk memastikan responden yang dipilih adalah bersesuaian dengan kehendak dan objektif kajian ini.

Kriteria Penerimaan Responden

1. Warganegara Malaysia

2. Berumur melebihi 13 tahun

3. Memahami Bahasa Melayu atau Bahasa Inggeris

4. Melalui proses pemulihan di Klinik Kesihatan

5. Memberi keizinan untuk menyertai soal selidik ini

6. Stabil dan mampu menjawab borang soal selidik yang diberi (bagi responden yang tidak berupaya menjawab soalan yang dikemukakan, penjaga/ petugas yang bertanggungjawab boleh membantu menjawab soalan tersebut)

7. Kriteria Penolakan Responden

8. Responden terlalu lemah/sakit untuk menjalani proses temubual

9. Tidak boleh bercakap dan sukar memahami

10. Nyanyuk

11. Tidak memberi keizinan untuk menyertai kajian ini

\section{KAEDAH PERSAMPELAN}

Persampelan yang digunakan di dalam kajian ini ialah persampelan bertujuan. Subjek yang dipilih menerusi kajian ini lazimnya mempunyai kaitan dengan kajian yang sedang dijalankan. Pemilihan sampel dalam kaedah persampelan bertujuan adalah berperanan untuk mendapatkan individu yang memenuhi kriteria-kriteria yang telah ditetapkan oleh pengkaji ${ }^{13}$ (Tongco 2007). Tambahan pula, persampelan bertujuan boleh dikaitkan dengan teknik persampelan bukan kebarangkalian. Pemilihan responden dari satu populasi hendaklah mengikut tujuan kajian dan pengkaji mempertimbangkan sendiri untuk memilih responden yang sesuai dengan tujuan kajian. Maklumat yang dikehendaki oleh setiap pengkaji mestilah seiring dengan pemilihan sampel yang dibuat berdasarkan tingkah laku, situasi dan individu yang dikaji oleh pengkaji ${ }^{14}$ (Sabitha 2005).

SAIZ SAMPEL

Bagi mendapatkan saiz sampel yang sesuai, formula Kish (1965) telah digunakan iaitu dengan mengambil seramai 30 orang responden.

\section{INSTRUMEN KAJIAN}

Pengkaji menggunakan borang soal selidik yang diedarkan kepada responden. Setiap set borang soal selidik diselitkan dengan lampiran A yang memberi maklumat mengenai kajian ini kepada responden. Lampiran A mengandungi maklumat ringkas tentang kajian, faedah penyelidikan, kerahsiaan, penyertaan, penarikan diri, bayaran yang dikenakan serta pampasan. Manakala, lampiran B pula merangkumi borang kebenaran untuk mendapatkan tandatangan daripada responden sebagai tanda persetujuan menyertai kajian ini. Lampiran C pula merupakan borang soal selidik yang mengandungi empat bahagian: 1) bahagian A (maklumat asas responden); 2) bahagian B (borang pengukuran kualiti hidup: ss-qol); 3) bahagian $\mathrm{C}$ merangkumi pengukuran sokongan sosial kajian hasil perubatan atau lebih dikenali sebagai "medical outcome study social support survey (mos-sss)" dan 4) bahagian D (pengukuran faktor-faktor pemulihan).

\section{ANALISIS DATA}

Dalam penganalisisan data, proses penelitian perlu dilakukan untuk menentukan jenis data analisis yang sesuai digunakan dalam kajian. Oleh itu, pengkaji telah memilih untuk menggunakan kaedah kuantitatif dalam kajian ini. Teknik analisis yang sesuai perlu diaplikasikan dan dipersembahkan dalam kajian setelah pengumpulan data dilakukan. Kajian ini menggunakan analisis data melalui perisian SPSS yang bertujuan untuk menganalisis angka atau nombor secara lebih ringkas dan kompleks. Seterusnya SPSS juga memudahkan pengkaji menganalisis, menafsir, memahami, memasukkan data serta membuat keputusan ${ }^{15}$ (Rahim 2013).

Analisis deskriptif digunakan untuk menganalisis data dalam kajian kuantitatif. Teknik analisis ini digunakan dengan cara menggambarkan data yang akan terkumpul tanpa membuat kesimpulan secara umum ${ }^{16}$ (Hussain, 2012). Di samping itu, teknik analisis ini menjelaskan ciri-ciri utama maklumat yang bertujuan untuk meringkaskan sampel seperti dalam pengukuran nilai purata. Seterusnya, analisis ini juga memperincikan ciri-ciri pembolehubah yang menunjukkan kekerapan, peratusan, nilai purata, sisihan piawai, median dan julat yang memberikan gambaran yang lebih jelas tentang sosiodemografi responden termasuklah jantina, umur, 
tahap pendidikan, bangsa, status perkahwinan, agama, asal, bilakah mendapat serangan strok pertama dan sejarah penyakit yang dihidapi oleh responden.

Di samping itu, analisis statistik inferensi juga digunakan dalam kajian ini. Pengkaji menggunakan teknik analisis inferensi untuk menghuraikan hubungan antara pembolehubah dengan menggunakan SPSS versi 22.0. Penggunaan SPSS membantu pengkaji mendapatkan analisis data yang tepat. Seterusnya, pengkaji mempersembahkan analisis data dalam bentuk jadual, statistik dan carta ordinal. Ujian yang digunakan dalam kajian ini ialah ujian T. "Ujian T" dikira berdasarkan perbezaan nilai purata dan varians yang menunjukkan dua keadaan kumpulan dan memahami perbandingan antara kumpulan tersebut. Selain itu, ujian ANOVA juga digunakan bagi membandingkan nilai purata bagi tiga atau lebih kumpulan sampel yang tidak bersandar bagi menentukan sama ada terdapat perbezaan nilai purata yang signifikan ataupun tidak berdasarkan sampel yang sudah dipilih. Analisis bivariabel juga digunakan dengan melihat perbandingan, hubungan dan sebab, pembolehubah yang bergantung dengan nilai-nilai pembolehubah lain seperti pembolehubah bersandar dan pembolehubah tidak bersandar. Di samping itu, kajian kolerasi digunakan dalam kajian ini. Kajian kolerasi adalah reka bentuk kajian bukan eksperimen. Pengkaji dapat mengetahui kolerasi atau perhubungan antara pembolehubah dan dua aspek yang dikaji sama ada corak perhubungan yang wujud berbentuk negatif, positif atau tiada perkaitan langsung dan darjah kekuatan perhubungan antara pembolehubah akan diukur dalam bentuk pekali korelasi (r).

\section{KEPUTUSAN DAN PERBINCANGAN}

Hasil kajian memfokuskan hubungan kekeluargaan, perlakuan, tingkah laku serta emosi di antara responden dan pasangan. Keputusan menunjukkan bahawa hampir $80.0 \%$ responden tidak mempunyai sejarah penderaan sebelum ini dan tidak melakukan keganasan rumah tangga terhadap pasangan mereka.

Sebanyak 39.4\% responden sangat bersetuju bahawa keganasan rumah tangga adalah jenayah, berbanding 7.1\% responden yang tidak bersetuju. Hal ini menunjukkan

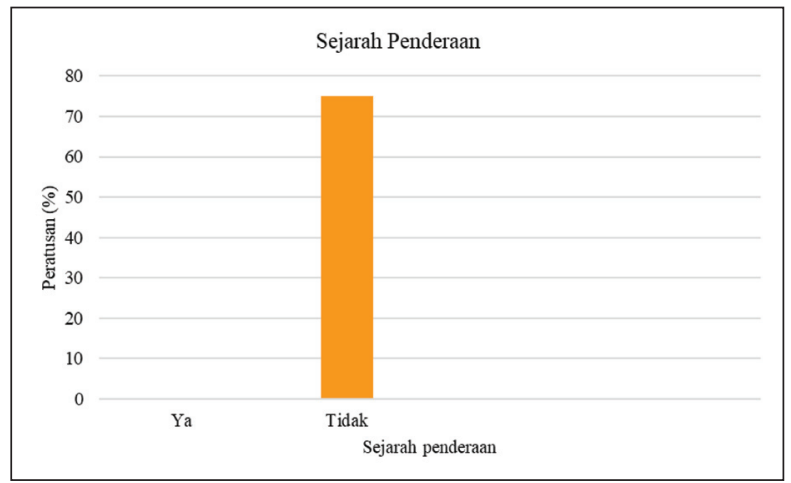

bahawa, kebanyakan responden mengambil tahu tentang permasalahan keganasan rumah tangga dan tidak menyokong sisi gelap penderaan yang berlaku di dalam dan luar institusi kekeluargaan

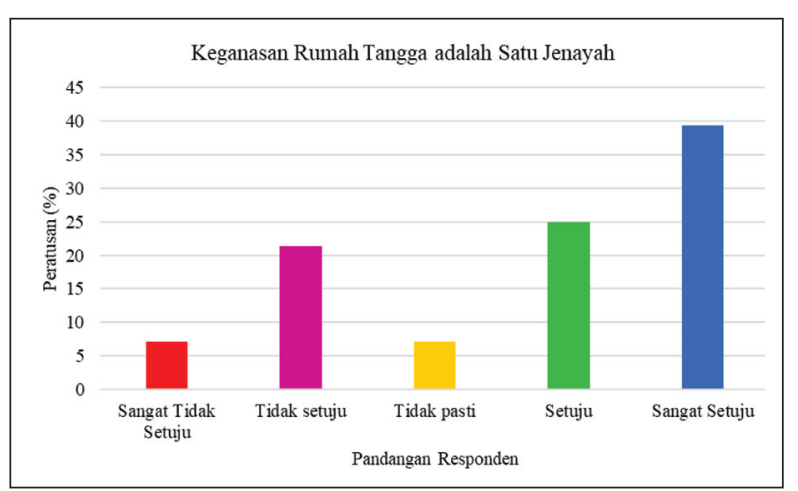

Selain itu, hampir $70.0 \%$ responden sangat meminati filem-filem yang berunsurkan aksi-aksi ekstrem iaitu filem-filem yang dilakonkan dengan menggunakan watak-watak yang ganas seperti berunsurkan pembunuhan, penderaan fizikal, penganiayaan, dan keganasan. Hal ini menunjukkan bahawa filem-filem yang menjadi kegemaran responden adalah filem yang boleh menimbulkan keinginan serta idea kepada mereka untuk melakukan aksi-aksi tersebut di dunia realiti. Hal ini boleh menjadi faktor yang mendorong mereka untuk bertindak di luar jangkaan dan lebih berani untuk melakukan perkara-perkara yang berunsurkan aksi-aksi merbahaya sehingga boleh mengundang padah kepada diri responden dan juga masyarakat sekeliling. Namun masih terdapat responden yang tidak menjadikan filemfilem ekstrem sebagai filem kegemaran walaupun ia hanya menjangkau kepada 5.0\% responden sahaja.

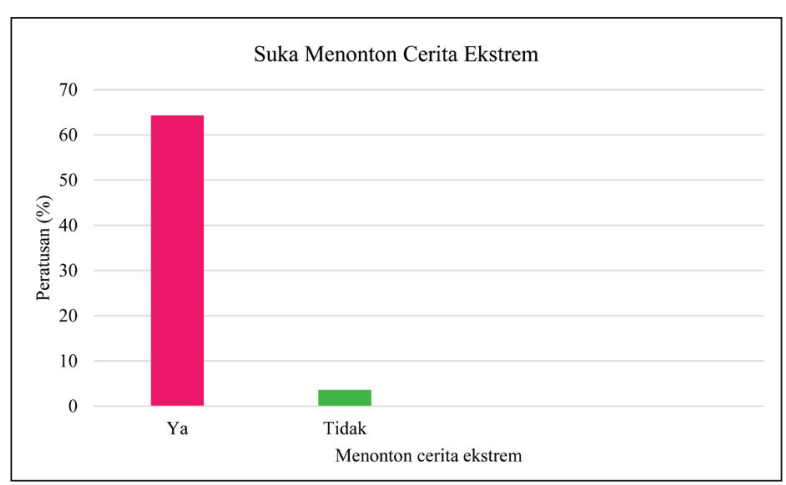

Seterusnya, data menunjukkan bahawa $36.0 \%$ responden bersetuju bahawa layanan mereka terhadap pasangan berubah setelah mengambil dadah. Hal ini menunjukkan kebanyakan responden mengakui bahawa dadah memberi kesan terhadap perubahan sikap dan tingkah-laku responden terhadap pasangan mereka sama ada layanan yang diberikan adalah semakin baik ataupun semakin buruk bergantung kepada responden sendiri. 


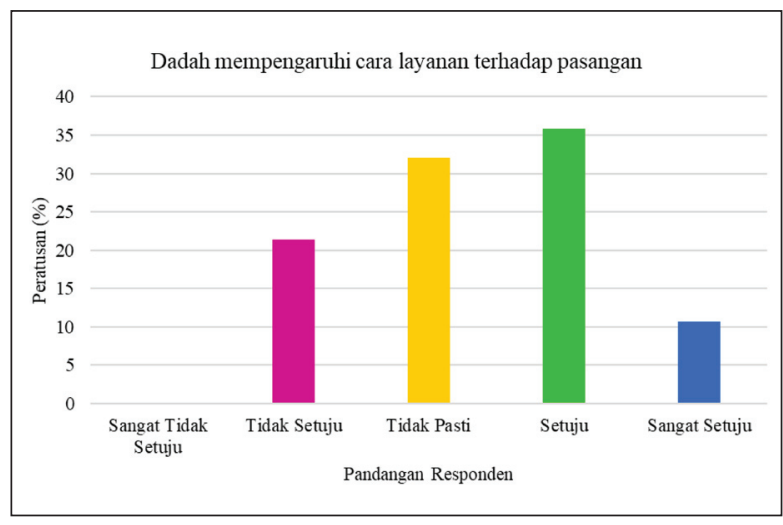

Data juga membuktikan bahawa sebanyak 22.0\% responden merasakan pasangan mereka berasa risau dan takut apabila bersama mereka. Melalui hasil ini, pengkaji dapat melihat bahawa kebanyakan responden mengakui pasangan mereka berasa tidak selamat ketika responden ada bersama. Hal ini menunjukkan pasangan mereka sendiri tidak mempercayai mereka dan menganggap responden akan melakukan perkara yang boleh mendatangkan kesan yang buruk ke atas diri dan keluarga pasangan. Oleh itu, hal ini membuktikan bahawa hampir $75.0 \%$ responden berkemungkinan pernah bertindak kasar dari segi tingkah laku dan percakapan terhadap pasangan mereka sehingga menyebabkan pasangan mereka berasa bimbang apabila responden mendekati mereka.

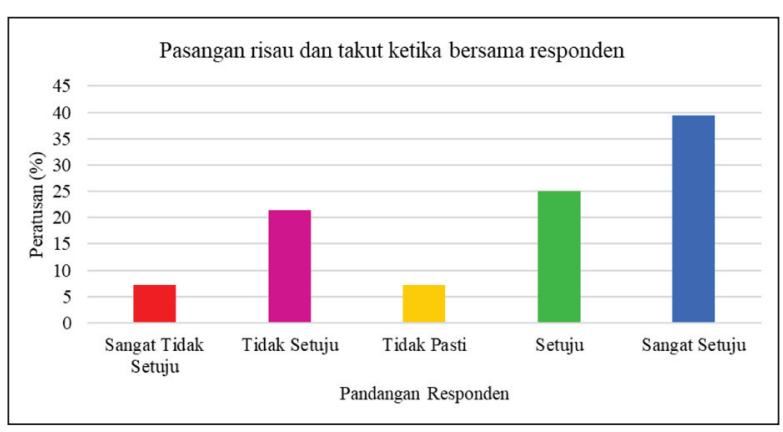

Keganasan rumah tangga merupakan satu bentuk perbuatan yang mendera di dalam sesebuah perhubungan yang dilakukan oleh pasangan untuk mendapatkan dan mengekalkan kuasa serta untuk mengawal pasangannya. Terdapat pelbagai jenis perbuatan yang boleh dikategorikan sebagai keganasan rumah tangga seperti penderaan emosi, penderaan fizikal, penderaan fisiologi, penderaan seksual dan juga penderaan kewangan. Penggunaan dadah merupakan salah satu faktor yang menyebabkan berlakunya keganasan rumah tangga. Pergaduhan boleh berlaku disebabkan oleh masalah kewangan seperti penagih mengambil duit pasangan atau membeli dadah dengan menggunakan duit yang diperuntukkan untuk membeli barang-barang keperluan harian ${ }^{17}$ (Smith \& Powell 2011). Apabila seseorang itu menjadi penagih dadah, otak mereka akan direncanakan untuk sentiasa menggunakan dan memerlukan dadah tersebut tanpa mengira kesannya ke atas perangai, perbuatan atau tingkah laku mereka. Hal ini boleh menyebabkan penagih menjadi seorang yang menjengkelkan, cepat marah, ganas serta suka mengawal. Penagihan dan keganasan rumah tangga mempunyai persamaan seperti hilang kawalan, perbuatan yang berterusan walaupun ia mendatangkan kesan yang negatif, bertambah buruk jika berterusan dan kedua-duanya melibatkan penafian dan memalukan.

Terdapat hubung kait di antara penagihan dan keganasan rumah tangga. Penagihan dan keganasan rumah tangga biasanya berlaku bersama atau serentak kerana dadah akan merencatkan pemikiran dan mental individu terbabit yang seterusnya akan menyebabkan mereka lebih cenderung untuk terlibat dengan perbuatan yang tidak baik. Selain itu, keadaan mereka yang khayal ketika di bawah pengaruh dadah akan menyebabkan mereka menjadi di luar kawalan. Mereka akan melakukan sesuatu perkara tanpa memikirkan kesan perbuatan tersebut. Tambahan lagi, apabila seseorang berada dalam keadaan khayal, kapasiti mereka untuk membuat keputusan akan menurun. Mereka akan tidak dapat membuat keputusan dengan betul. Sesetengah jenis dadah seperti stimulant boleh menyebabkan seseorang itu menjadi paranoid. Sifat mereka yang paranoid inilah yang akan menyebabkan perbuatan yang melampau atau ekstrem berlaku dalam kalangan penagih dadah ${ }^{18}$ (Zilberman \& Blume 2005).

\section{KESIMPULAN}

Oleh itu, kadar keganasan rumah tangga dalam kalangan komuniti pada masa kini hendaklah dihapuskan dan dilupuskan dari muka bumi ini sepertimana yang berlaku pada penyakit-penyakit berjangkit yang telah berjaya dikawal dan akhirnya dihapuskan. Namun malangnya, penyakit keganasan rumah tangga masih tidak dapat dibasmi atau dihapuskan. Keganasan rumah tangga adalah satu penyakit yang telah merebak kepada seluruh masyarakat dan memberi impak negatif kepada semua orang tanpa mengira jantina, bangsa, umur, orientasi seksual, status socio-ekonomi, kewarganegaraan mahupun agama.

Sebagai seorang lelaki yang bergelar ketua keluarga, mereka tidak seharusnya memainkan peranan tersebut secara tidak adil terhadap pasangan. Mereka mungkin dianggap sebagai ketua dan pemimpin dalam keluarga, namun mereka memimpin dengan cara yang salah dan bersifat autokratik. Keadaan ini menyebabkan hubungan kekeluargaan terutamanya antara suami dan isteri tidak harmoni dan tidak tenteram. Melalui hasil kajian ini, pengkaji dapat melihat bahawa tahap keganasan rumah tangga dalam kalangan pengguna opiat di Klinik Kesihatan Bukit tunggal berada pada paras yang sederhana. Masih terdapat segelintir daripada mereka yang melakukan kekerasan terhadap pasangan seperti 
memukul, menghina, mengkritik, mengugut untuk membunuh, dan memaksa pasangan untuk melakukan sesuatu perkara untuk kepentingan diri mereka. Sikap tegas seorang suami bukanlah dengan cara kekerasan, penghinaan dan ugutan tetapi dengan cara yang berhikmah dan melalui tingkah-laku yang sewajarnya dilakukan oleh seorang suami yang baik dan penyayang. Kefahaman mereka berhubung dengan keganasan rumah tangga juga masih kurang dan perlu diterangkan dan dididik akan hak-hak mereka oleh pihak yang bertanggungjawab dalam memastikan keganasan rumah tangga dapat diatasi secara berperingkat dalam kalangan mereka.

\section{NOTA}

Hanafi, A., \& Rohani, A. R. Kekerasan Rumah Tangga terhadap Wanita: Kajian Perbandingan Sosio-Perundangan Di Malaysia Dan Indonesia. (2015). (14), Al 'Adl, 117-142

2 AADKMaklumat Dadah 2016 (2018th ed.). Agensi Anti-Dadah Kebangsaan, Malaysia: Agensi Anti-Dadah Kebangsaan, (2016.

3 Agensi Anti-Dadah Kebangsaan (AADK) 2016. https://www.adk. gov.my/Orang-Awam/Statistik Dadah/. (Accessed on December 2016.

4 AHRD. ASEAN Human Rights Declaration and the Phnom Penh Statement on the Adoption of the ASEAN Human Rights Declaration (AHRD). ASEAN Secretariat; Jakarta, 2013.

5 ASEAN. Declaration of the Advancement of Women in the ASEAN Region Bangkok, Thailand, 1988, 5 July 1988. Retrieved from https://asean.org/?static_post=declaration-of-the-advancement-ofwomen-in-the-asean-region-bangkok-thailand-5-july-1988.

6 ASEAN Declaration on the Elimination of Violence against Women in the ASEAN Region. 2004. Retrieved from https:// asean. org/?static_post=declaration-on-the-elimination-of-violenceagainst-women-in-the-asean-region-4

7 AHRD. ASEAN Human Rights Declaration and the Phnom Penh Statement on the Adoption of the ASEAN Human Rights Declaration (AHRD). ASEAN Secretariat; Jakarta, 2013.

8 Butchard, A., Gracia-Moreno, C., \& Mikton, C. WHO-Preventing Intimate Partner And Sexual Violence Against Women: Taking Action and Generating Evidence. World Health Organization, Geneva, 2010.

9 Cherrie, L. M. Loving in the War Years. South End Press.Cambridge, Massachusetts, 2000

10 Csete, J., Kamarulzaman, A., Kazatchkine, M., Altice, F., Balicki, M., Buxton, J. \& Hart, C. Public health and international drug policy. (2016) 387(10026), The Lancet, 1427-1480.

11 Mann, C. J. Observational research methods. Research design II: cohort, cross sectional, and case-control studies. (2003) 20 (1) Emergency Medicine Journal: EMJ, 54-60.

12 Sedgwick, P. (2014). Cross sectional studies: advantages and disadvantages. BMJ, 348(2276), 1-2.

13 Tongco, M. D. C. Purposive Sampling as a Tool for Informant Selection. (2007) 5 Ethnobotany Research\& Applications, 147158.

14 Sabitha, M. Kaedah penyelidikan sains sosial. Prentice Hall/Pearson Malaysia, 2005. Retrieved from https://books.google.com.my/ books?id=LbNDNwAACAAJ

15 Rahim U. IBM SPSS Statistics for window. Pejabat Teknologi Maklumat, 2013.

16 Hussain, M. Descriptive statistics-presenting your results I. (2012) 62(7), J Pak Med Assoc, 741-743.

17 Smith, M., \& Powell, P. Domestic Violence: An Overview. Uniersity of Nevada Cooperative Extension, 2011, 1-4.

18 Zilberman, M. L., \& Blume, S. B. Domestic violence, alcohol and substance abuse. (2005) Revista brasileira de psiquiatria (Sao Paulo, Brazil: 1999), 27 Suppl 2, S51-5.

\section{RUJUKAN}

AADK. 2016. Maklumat Dadah 2016 (2018th ed.). Agensi Anti Dadah Kebangsaan, Malaysia: Agensi Anti Dadah Kebangsaan.

Agensi Anti Dadah Kebangsaan (AADK). 2016. https://www. adk.gov.my/Orang-Awam/Statistik-Dadah/. Accessed on December 2016.

AHRD. 2013. ASEAN Human Rights Declaration and the Phnom Penh Statement on the Adoption of the ASEAN Human Rights Declaration (AHRD). ASEAN Secretariat; Jakarta.

ASEAN. 1988. Declaration of the Advancement of Women in the ASEAN Region Bangkok, Thailand, 5 July 1988. Retrieved from https://asean.org/?static_post=declarationof-the-advancement-of-women-in-the-asean-regionbangkok-thailand-5-july-1988.

ASEAN. 2004. Declaration on the Elimination of Violence against Women in the ASEAN Region. Retrieved from https://asean.org/?static_post=declaration-on-theelimination-of-violence-against-women-in-the-aseanregion-4

AHRD. 2013. ASEAN Human Rights Declaration and the Phnom Penh Statement on the Adoption of the ASEAN Human Rights Declaration (AHRD). ASEAN Secretariat; Jakarta.

Butchard, A., Gracia-Moreno, C. \& Mikton, C. 2010. WHOPreventing Intimate Partner And Sexual Violence Against Women: Taking Action And Generating Evidence. World Health Organization, Geneva.

Cherrie, L. M. 2000. Loving in the War Years. South End Press. Cambridge, Massachusetts.

Csete, J., Kamarulzaman, A., Kazatchkine, M., Altice, F., Balicki, M., Buxton, J. \& Hart, C. 2016. Public health and international drug policy. The Lancet, 387(10026), 1427-1480.

Hanafi, A., \& Rohani, A. R. 2015. Kekerasan Rumah Tangga Terhadap Wanita: Kajian Perbandingan Sosio-Perundangan Di Malaysia Dan Indonesia. Al 'Adl, VII (14), 117-142.

Hussain, M. 2012. Descriptive statistics-presenting your results I. J Pak Med Assoc, 62(7), 741-743.

Mann, C. J. 2003. Observational research methods. Research design II: cohort, cross sectional, and case-control studies. Emergency Medicine Journal: EMJ, 20(1), 54-60.

Rahim, U. 2013. IBM SPSS Statistics for window. Pejabat Teknologi Maklumat.

Sedgwick, P. 2014. Cross sectional studies: advantages and disadvantages. BMJ, 348(2276), 1-2.

Sabitha, M. 2005. Kaedah penyelidikan sains sosial. Prentice Hall/Pearson Malaysia. Retrieved from https://books. google.com.my/books?id=LbNDNwAACAAJ

Smith, M., \& Powell, P. 2011. Domestic Violence: An Overview. Uniersity of Nevada Cooperative Extension, 1-4.

Tongco, M. D. C. 2007. Purposive Sampling as a Tool for Informant Selection. Ethnobotany Research\& Applications, 5, 147-158.

Zilberman, M. L., \& Blume, S. B. 2005. Domestic violence, alcohol and substance abuse. Revista brasileira de psiquiatria (Sao Paulo, Brazil: 1999), 27 Suppl 2, S51-5. 
